\title{
Implementation of Technical Guidance on the Results of Indonesian Madrasah Competency Assessment 2021
}

\author{
Husniyatus Salamah Zainiyati ${ }^{1, *}$ Imam Suyitno $^{2}$
}

\author{
${ }^{1}$ Universitas Islam Negeri Sunan Ampel Surabaya, Indonesia \\ ${ }^{2}$ Universitas Negeri Malang, Indonesia \\ *Corresponding author. Email husniyatussalamah@uinsby.ac.id
}

\begin{abstract}
This study aims to describe the implementation of technical guidance (imtek) as the results of the AKMI 2021, the challenges during the implementation of technical guidance, and alternative solutions for the improvement. This study used qualitative approach with the data were collected through interviews, observations, and document studies. The data were analyzed through the stages of data selection, data reduction, data presentation, and drawing conclusions. The study resulted in the findings that (1) the follow-up technical guidance of AKMI carried out in 4 batches with a blended learning model and 4 batches fully online involving 12,065 teachers and 513 instructors had achieved the specified target; (2) a number of challenges faced during the implementation of the program are (a) participants feel bored with the online model, (b) the implementation of bimtek is often constrained by the network, (c) Bimtek participants feel that they are not in accordance with their field and lack discipline, (d) the competence of regional instructors and local instructors need to be improved, (e) the quality of LMS needs to be upgraded, and (f) understanding of the material about AKMI is still lacking; and (3) alternative solutions that need to be done are (a) strengthening understanding of AKMI through more intensive socialization and coordination with related institutions, (b) understanding and improvement of related parties regarding the direction of AKMI bimtek, which is not deepening the material for subjects Indonesian, Natural Sciences, Mathematics and Social Sciences, but develop literacy skills that have an impact on various subjects. It is expected that the results of this research may contribute to materials for improving the implementation of the AKMI Bimtek next terms.
\end{abstract}

Keywords: AKMI, Bimtek, Implementation of technical guidance, Challenges, Solution.

\section{INTRODUCTION}

Based on data from the Program for International Student Assessment (PISA) test results in the core fields of study taught in schools, namely reading, mathematics, and science in 2012, 2015 and 2018 show that the quality of education in Indonesia can be said to be still low; despite the increase in 2015, Indonesia's PISA score relatively fell in all fields in 2018, with the sharpest decline occurred in the field of reading [1] as illustrated in the Figure 1.

The low quality of education becomes a concern of various groups, especially those who are engaged and involved in the field of education. Many education experts argue that the quality of the education of a country could be improved if the the state's per capita income is good. The reality shows something different. Kompas Daily, March 16 2018, reported that the World Bank made Vietnam a country whose quality of education has accelerated even though the per capita income is relatively low at US\$ 5,668, half of Indonesia, which is US\$10,385. This fact shows that per capita income is not directly proportional to the educational attainment. The quality of education in Vietnam is moving forward because the curriculum content starts from primary and secondary education according to the needs of students and their era. 


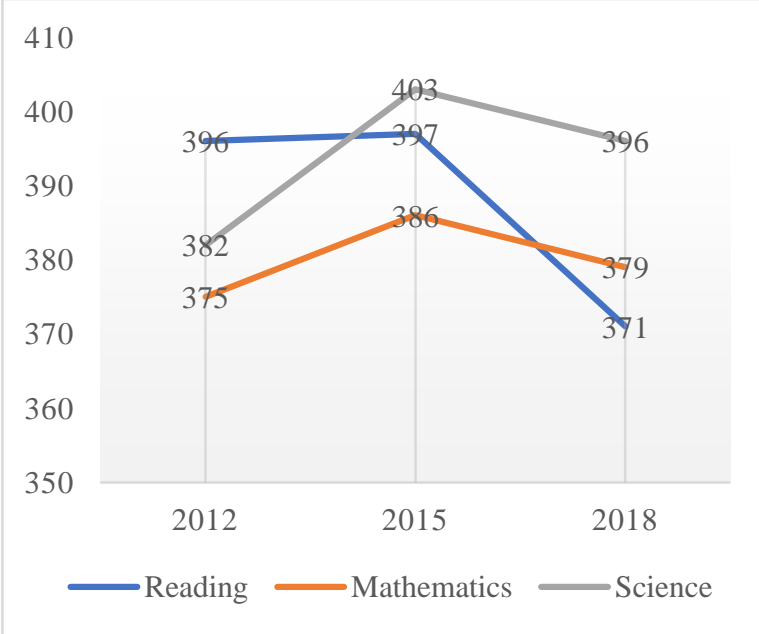

Figure 1 Indonesia's PISA Scores (2012, 2015, 2018).

According to Munif Chatib, there are four basic criteria for improving the quality of education in Indonesia, namely teacher quality, understanding the needs of students, understanding local wisdom and local potential, and designing a decentralized curriculum. [2]

The Ministry of Religious Affairs (MORA) of the Republic of Indonesia in collaboration with the World Bank seeks to improve the quality of education, especially in the context of madrasah through alternative solutions that are carried out in a systemic and sustainable manner. Improving the quality of madrasah education is realized in a program called AKMI (Indonesian Madrasah Competency Assessment). Improving the quality of learning in madrasahs is the main goal of the AKMI program. In line with this improvement in the quality of learning, madrasah teachers are the frontliners who determine the success of the long-series activities of AKMI. Madrasah teachers need to receive adequate debriefing through the implementation of strategic technical guidance (bimtek) so that teachers' understanding, skills, and performance can be improved.

Stages of AKMI activities such as the preparation of the AKMI framework, the preparation of the stimulus, and the development of instruments have started to be implemented since 2020. In 2021, the implementation of AKMI is specified to the Madrasah Ibtidaiyah (MI) (elementary level). As the response to the results of the assessment, learning improvement modules and the implementation of technical guidance (bimtek) for the MI teachers were prepared. The implementation of AKMI was carried out simultaneously on November 8, 2021 at 12,809 madrasahs with a total of 350,135 students.

This article is intended to describe the implementation of the follow-up action in the form of technical guidance (bimtek) on the results of AKMI 2021. In addition, it also explores the challenges faced during the implementation of the bimtek as well as the alternative solutions to make it better. It is expected that the results of this research may contribute as the basis for improving the implementation of AKMI bimtek in the future.

\section{THEORETICAL FRAMEWORK}

\subsection{Indonesian Madrasah Competency Assessment (AKMI)}

AKMI is an evaluation instrument that functions as a diagnostic tool for the competence of the students from madrasah. In this case, assessment for learning does not only concern the quality of the students, but also about how teachers employ the assessments [3]. The evaluation instrument developed in the AKMI program is used to diagnose madrasah students' competence in reading, numeracy, science, and sociocultural literacy skills. The evaluation instrument is in the form of a set of questions by considering the cognitive level and thinking demands that are expected to be mastered by madrasah students relevant with the $21^{\text {st }}$ century educational paradigm.

The forms of questions developed in AKMI instrument consist of multiple choice questions with one correct answer choice, multiple choice questions with more than one correct answer choice, true-false answer choices with reasons, options answers agree-disagree with reasons, finding the relation (match-making), and short answers. The content or domain tested is based on the characteristics of each literacy with a personal, sociocultural, scientific, and religious context.

The assessment of AKMI program was carried out in a multistage assessment with the rationale it may accurately describe an overview of students' competence objectively, that the students would be categoried into the proficiency level, intervention needed, basic level, capable level, skilled level, and need creative space. The results of the assessment are expected to become objective scientific data that are essential for the related parties, especially teachers, in understanding the characteristics of their students' competencies so that they may take strategic actions in overcoming the students' weaknesses through appropriate learning activities.

In order to follow up the results of AKMI, it is necessary to prepare learning modules for each literacy skill, namely reading literacy learning modules, numeracy literacy learning modules, scientific literacy learning modules, and sociocultural literacy learning modules. These learning modules would be a set of teaching materials arranged in the form of a module developed based on the framework used in developing AKMI items. The learning modules developed for each literacy refer to the overview of students' proficiency levels (which may vary from the results of the AKMI assessment) so that the learning modules consist of learning modules for certain levels that require intervention, basic, proficient, skilled, and need creative space. Each module contains 4-5 learning activities according to the cognitive level demands targeted in the AKMI framework. Each module contains general insights about the respective literacy skill and each 
learning activity has a focus on achievements, learning mechanisms, theoretical insights, learning models and steps, reflection, and follow-up.

\subsection{Characteristics of Instructors and Participants of the Training}

There are several factors which support the success of training or technical guidance (bimtek), one of which is the role of the instructors. Educational instructors play a role in providing input, carrying out the process, and producing participant outputs that meet the high quality targets. The participants of AKMI bimtek were adults so the learning provided cannot be the same with learning for students at the school level or students at college. According to Knowles [4], the concept of adult learning or andragogy has general characteristics, namely (1) a more qualified self-concept, namely their responsibility in carrying out greater training and an independent attitude without depending on others; (2) having many diverse experiences due to the fact that the phases of life that adults are wider than children or adolescents; (3) mature learning readiness where they are better able to control and divide and manage time and set priorities; (4) the orientation of learning is more to problemcenteredness because they are already members of the community so that learning that talks about facts and actuals in the community, or even their working environment, will have a great understanding impact for them; and 5) relying more on self-motivation to learn [5].

Professional instructors utilize information from the characteristics of the participants to serve as reference material in selecting and designing activities to be carried out in the classroom. By referring to the characteristics of the participants, the principles are created that can be used as a reference for the instructor. These principles are:

- Involvement. Participants are involved in all training activities from planning, implementation, to evaluation, such as learning contracts to be more effective for the instructors and participants before the activities are carried out. This involvement will provide a feeling of belonging and need from the learning carried out. This feeling will encourage them to follow the learning with enthusiasm and without feeling burdened;

- Experience. Professional instructors should provide new experiences and perspectives for participants;

- Relevance to life. The activities given by the instructor are good ones that are related to people's lives so that participants will be enthusiastic about participating in the activities because they think that the activities they have done will have an impact on themselves and the community in their lives; and

- Problem-centered. Problem-oriented activities are needed as participants have had various kinds of experiences, as well as experience facing a problem and its handling so that problem-based learning will be easy to follow and interesting for participants.

\section{METHODS}

This study used a qualitative approach to describe and understand the underlying meaning of participant's behavior, describe the setting and complex interactions, and explore to identify the types of information [6]. Data collection was carried out through interviews, observation, and documentation. The interview technique was carried out by meeting directly with the informants and also intense communication through social media such as Zoom and WhatsApp. Through this method, researchers obtained data about the implementation of the AKMI bimtek and the challenges during the implementation of the bimtek. Participant observation was carried out by following and observing the implementation of AKMI bimtek both in-person and online. Documentation could be in the form of notes, writings and pictures, for example documents from AKMI. This document study is a complement to the use of interview and observation methods. The informants of this research were the chairman and secretary of AKMI, national instructors, regional Instructors and local instructors. Data analysis used three activities, namely data selection, data reduction, data presentation, and drawing conclusions or verification [7].

\section{RESULTS AND DISCUSSION 4.1. Implementation of AKMI Bimtek}

The implementation of AKMI 2021 took place at 12,809 madrasahs, attended by 350,135 students of MI across 34 provinces in Indonesia. The assessment required 54,981 rooms and supervisors. The results of AKMI can be seen in the classification of achievements and types of literacy as described in the figure below:

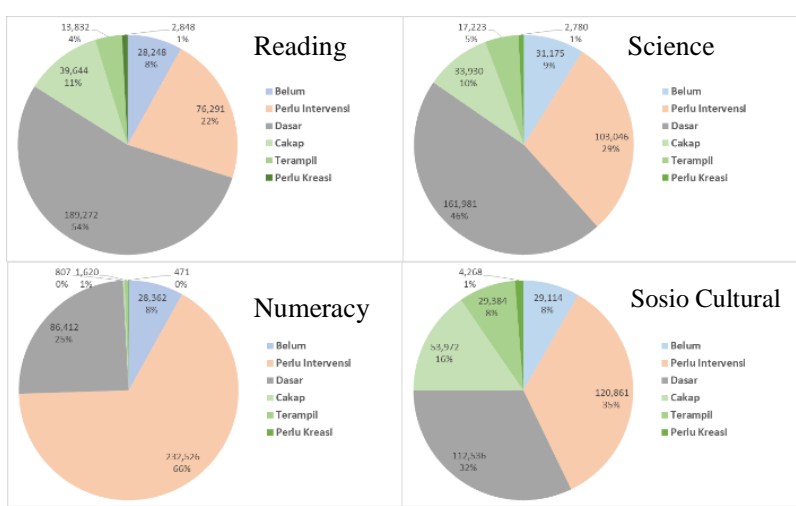

Figure 2 Classification of achievement and type sof literacy.

The data show that reading literacy skills are $54.1 \%$, science is $46.3 \%$ and sociocultural is $32.1 \%$ at the basic proficiency level, while numeracy literacy is at the proficiency level which requires intervention of $24.7 \%$. In order to follow up on the results of AKMI, AKMI Bimtek is needed. The bimtek is an effort to provide training through technical guidance to prospective instructors or teachers in the implementation of learning more creatively and innovatively. The training should be carried out in stages starting from the national, provincial 
(regional), and municipal or local levels. AKMI Bimtek has the following objectives:

- Reading Literacy, equipping individuals to develop the ability to understand, use, evaluate, reflect on various reading (whatever they read), develop their capacity as citizens of Indonesia and citizens of the world, and contribute productively to the society [8];

- Numerical Literacy, equipping individuals to develop the ability to think using concepts, procedures, facts, and mathematical tools and solve everyday problems in various types of contexts that are relevant for individuals as Indonesian citizens and citizens of the world;

- Scientific Literacy, equipping the individuals to develop their ability to be more careful and careful, responsible, confident, highly motivated, selfunderstanding, and values, and foster curiosity, scientific and critical thinking, independence, development of a caring attitude and responsibility towards the natural and social environment [9]; and

- Sociocultural Literacy, equipping individuals to develop the ability to be wiser in dealing with various problems, be more humane in interacting and communicating with the community and considerate in social life.

Thus, AKMI Bimtek aims to build individuals with more dignity and able to think logically and rationally, understand and communicate scientific knowledge honestly and responsibly, use polite and humane language and solve various problems encountered in life in the community, including proposing wise and fair solutions.

The implementation of AKMI Bimtek for the first batch of madrasah teachers was on November $8^{\text {th }}, 2021$, for 14 calendar days, while the mechanism for the activities is regulated as follows:

- The training was conducted in two modes, blended and full online.

- The online and in-person mechanism was carried out as follows:

a) First online session for 3 days

b) In-person for 4 days (the session was designed for literacy)

c) Second online session for 7 days: online clinic

- Full online mechanism was conducted as follows:

a) Asynchronous online that the participants were doing their independent learning

b) Synchronous online session carried out 3 times (the opening, in the mid-session, and at the end)

The following is the number of batches and participants who were attending AKMI Bimtek:

Table 1. Total participants and models of AKMI Bimtek

\begin{tabular}{|c|l|c|c|}
\hline \multirow{2}{*}{ No. } & \multirow{2}{*}{ Clusters } & \multicolumn{2}{|c|}{ Models } \\
\cline { 3 - 4 } & & Blended & Online \\
\hline 1. & Batch I & 2,484 & 1,500 \\
\hline
\end{tabular}

\begin{tabular}{|c|l|c|c|}
\hline \multirow{2}{*}{ No. } & \multirow{2}{*}{ Clusters } & \multicolumn{2}{|c|}{ Models } \\
\cline { 3 - 4 } & & Blended & Online \\
\hline 2. & Batch II & 883 & 3,068 \\
\hline 3. & Batch III & 1,371 & 1,080 \\
\hline 4. & Batch IV & 1,343 & 336 \\
\hline & Total & 6,081 & 5,984 \\
\hline & Total & 12,065 & \\
\hline
\end{tabular}

Source: AKMI Documents 2021

In terms of the instructors, the technical guidance they are listed in the following Table 2.

Table 2. Number of instructors

\begin{tabular}{|l|l|c|}
\hline No. & \multicolumn{1}{|c|}{ Types } & Total \\
\hline 1. & National instructors & 25 \\
\hline 2. & Regional instructors & 282 \\
\hline 3. & Local instructors & 206 \\
\hline & Total & 513 \\
\hline \multicolumn{2}{|c|}{ Source: AKMI Documents 2021 }
\end{tabular}

The success of AKMI follow-up program does not lie in the process of activities that have been carried out from the national level to the regional level, but in the quality of the process and learning outcomes obtained by students in madrasahs. The training should be supported by standards for the achievement of Bimtek.

The standard of competence that should be achieved by madrasah teachers in AKMI Bimtek is the changes in insight, skills, and attitudes towards a better direction and realizing it in learning process. In detail, the standards of achievement of the technical guidance are:

- Madrasah teachers have adequate understanding of the basic concepts, models, and learning procedures for reading literacy, sociocultural literacy, scientific literacy, and numeracy literacy;

- Madrasah teachers have an adequate understanding of the characteristics of the cognitive level of the students at various the proficiency levels, namely need intervention, basic, proficient, skilled, and need creative space levels;

- Madrasah teachers have an understanding of various learning models that can be applied in learning activities to support reading literacy, sociocultural literacy, scientific literacy, and numeracy literacy according to the diversity of characteristics of students' proficiency levels;

- Madrasah teachers master the skills of developing more creative and innovative literacy learning designs (reading, socio-culture, science, and numeracy) in accordance with the competencies to be achieved and the diversity of characteristics of students' skills.

- Madrasah teachers master the skills of applying literacy learning (reading, socio-culture, science, and numeracy) based on certain learning design that has been developed contextually. 
- Madrasah teachers show seriousness in developing their competencies through technical guidance activities carried out both online or offline/in-person;

- Madrasah teachers have a positive attitude to accept change and apply it in learning activities.

(AKMI Document, 2021)

Bimtek materials for the madrasah teachers include materials on AKMI and literacy learning materials (reading, sociocultural, science, and numeracy literacy skills). The AKMI material relates to the vision, mission, and characteristics of the policies in relation to the implementation of AKMI. Literacy learning materials include materials related to competencies that need to be mastered by the students, the content and context of the material being taught, learning mechanisms and procedures, learning models used, and examples of the implementation in learning activities and instructions. During Bimtek, the teachers received materials on literacy education (reading, sociocultural, science, and numeracy literacy) on an ongoing basis within a limited period of time. Therefore, the learning of each literacy needs to select and present material that really has the potential to equip the teachers to be able to achieve the targeted competency standards.

The materials for the technical guidance that have been compiled were integrated into the Learning Management System (LMS) at sekolahmu.com. In general, the content of the AKMI Bimtek LMS contains, 1) core content that fully describes each module per literacy, 2) important parts of the modules that are presented in a coherent manner the overall content to be used as material in the technical guidance, 3 ) the content is intended to trigger and stimulate teacher's creativity in developing innovative learning so that in the LMS content and tasks are also presented to check understanding and final assignments for deepening learning experiences, and 4) Final test to measure the achievement of understanding of the learning content.

It should be understood that AKMI Bimtek was not an in-depth material for certain subjects, but to change the mindset of teachers who have the principle that learning is only for achieving high test scores. AKMI Bimtek seeks to develop three dimensions in an integrated manner, e.g. cognitive, psychomotor, and affective abilities to make the teachers have competencies and tips in developing more creative and innovative learning [10].

\subsection{Challenges during the Implementation of Bimtek AKMI}

Based on the results of interviews with several informants and observations by the researchers during the implementation of the AKMI Bimtek (in-person and online), several challenges were found as follows:

- Duration and facilities. 1) Full online technical guidance was carried out for 14 days and it was boring when the regional and local instructors lacked of material and did not master the online classes; 2) the training duration for each literacy for madrasah teachers was short, so that the delivery of material could not be comprehensive and participants became confused when doing the assignments; 3 ) participants complained on the low internet network and expensive internet quota bills; 4) online guidance and technology were constrained by the network, ideally in remote areas that have difficult access to internet network; it was supposted to conduct the training inperson for more benefits.

- Participants. 1) Participants assigned by the madrasahs did not meet expectations (there were participants with qualification as school or technical operators, administration staff, treasurers and teachers whose specifications did not match with the program); 2) there were participants who have not been able to use digital technology, even those who did not have gadget and borrowed the devices from their relatives; 3 ) in online classes, participants were often only present for photo session; 4) there were several regions where the attendance in virtual/online classes wass not more than $60 \%$ of the total participants; and 5) lack of discipline of the participants during the online technical guidance, such as attending the program while cooking, ironing, eating, smoking, and often the microphone was not turned off so that it interfered with the concentration of the other participants.

- Regional and local instructors. In general, the competence of the regional and local instructors needs to be upgraded under some rationales, namely: 1) AKMI Bimtek was carried out in stages (from national to regional, from regional to local instructors). There might be potential for misunderstanding of the concept if the regional and local instructors did not understand the materials, such as procedures and strategies to make AKMI questions; 2) It is recommended that the instructors for MI teachers be from MI teachers so that they understand the daily discourse; 3) If you look at the flow of technical guidance, the national instructors should train the regional instructors and the regional instructors to train the local instructors. The role of the local instructors was to train the teachers and provide assistance to follow up the results of AKMI. The regional instructors of each region may be a companion during the training, the national instructors could monitor the activities during bimtek handled by the local instructors. The purpose of the flow is to build common perception. Another way is there should be some kind of briefing before the implementation of bimtek and an evaluation after the activities for the improvement of the next session.

- The use of LMS. 1) LMS were mixed, especially the access for the instructors was not available for the three-day online sessions; 2) During the Bimtek many participants were unable to open the LMS, so it was difficult to see the contents of the modules in the LMS. Some participants were able to access the LMS 
but the class did not match, for example class 068 but class 106 appeared in the LMS, so the quality of the LMS was getting worse; 3 ) The certificate feature that appears automatically from the LMS was not appropriate because participants who did not finish the assignments could also get a certificate; 4) LMS did not have a feature to upload a final project in the form of a learning video, so it was only sent to the instructor directly.

- Understanding on bimtek material. 1) AKMI is considered a new subject. For example, in reading literacy, participants were confused about why they use sub domains instead of Basic Competencies as in the current national curriculum; 2) literacy material was identified as a particular subject by the participants, for example reading literacy is considered as an Indonesian language lesson, scientific literacy is identical to science lessons, numeracy literacy is identical to mathematics; 3) the explanation of each literacy should be standardized, especially the explanation of each level of proficiency; 4) bimtek material actually strengthens the understanding that literacy is in accordance with the subjects. For example, scientific literacy all examples and practicums strengthen science subjects, preferably on how to teach not teaching science, but how scientific literacy is in classroom teacher subjects, language, civics, etc.; 5) understanding of the material was still low, especially in making scenarios that connect the level of proficiency with the material; 6) the material for each clinic should be standardized and indicators of achievement set, so that it was not dependant on the instructors; 7) during the technical guidance at madrasah level, the teachers immediately received 4 literacy materials at once, so that participants were a bit confused about understanding and applying them, such as the terms mentioned in the numeracy and reading; 8) the majority of participants still had difficulty integrating literacy in their learning. However, there were some participants who were able to integrate literacy skills in subjects, for example from participants in Sragen, Blitar, Kalimantan, and make student worksheet in accordance with the bimtek material.

\subsection{Alternative solutions needed for better AKMI}

\section{bimtek}

- Strengthening the common understanding upon AKMI by conducting more intensive socialization and coordination with related institutions.

- In addition to mastering the materials, regional and local instrctors should be required to understand the characteristics of the participants, and the activities during the training should be directed at problemcenteredness, so that in the implementation of the training not only participants gain teaching experience, but the instructors also process to become professional and inspiring instructors; [5] [10]

- In order to make Bimtek AKMI materials easier to understand, participants need to ignore and leave (a) confusion related to basic competencies (KD) in the current curriculum, (b) other thoughts about curriculum changes because the materials on literacy skills have nothing to do with them at all, (c) habits /routines that occur in daily learning, and (d) concerns about students' poor test results related to the implementation of AKMI, and (e) various abilities that are obtained through the four literacy skills are the integrity that is expected to be possessed by each individual. This ability becomes the spirit that supports all subjects, not only for Indonesian language, mathematics, science, and social studies subjects.

- In carrying out this Bimtek, participants and instructors are encouraged to think positively and be more futuristic that through AKMI, we may (a) understand scientifically and be more objective about the condition of students, (b) take strategic steps in improving the competence of students, and (c) find methods that accurate in building the competence and personality of students as a whole. Therefore, the direction of the AKMI follow-up technical guidance is not to deepen the material for the four subjects, but to develop literacy skills that have an impact on various subjects.

\section{CONCLUSION}

The up AKMI technical guidance (bimtek) was as the follow-up action to the results of AKMI assessment. The training was carried out in four batches through blended learning model and four batches through fullyonline session by involving 12,065 teachers and 513 instructors, and the training has achieved the specified targets. In addition, a number of challenges occurred during the implementation of bimtek namely (a) the participants felt bored with the online model, (b) the implementation of the technical guidance was often constrained by the internet network, (c) the participants felt that they are not in line with their fields and lack discipline, (d) the competence of the regional and local instructors still needs to be improved, (e) the quality of LMS needs to be improved, and (f) the understanding of the material about AKMI is still lacking. In regards with the challenges, some alternative solutions, namely (a) strengthening the understanding of AKMI through more intensive socialization and coordination with related institutions, (b) understanding and improvement of related parties regarding the direction of AKMI, that it is not deepening the materials for Indonesian language, science, mathematics and social studies subjects, but development of literacy skills that have been integral parts to various subjects. 


\section{AUTHORS' CONTRIBUTIONS}

Concept and framework of the study and correspondence by Husniyatus Salamah Zainiyati. Data collection and data analysis were carried out by Husniyatus Salamah Zainiyati and Imam Suyitno.

\section{ACKNOWLEDGMENTS}

The authors would like to thank Directorate for Curriculum, Infrastructure, Institutions, and Students Affairs, Ministry of Religious Affairs, Republic of Indonesia for the opportunity to be involved in the implementation of AKMI and relevant parties in Component 2. In addition, thank the instructors of AKMI Bimtek for their participation in this research.

\section{REFERENCES}

[1] Pusat Penilaian Pendidikan Balitbang Kemendikbud, "Pendidikan Di Indonesia Belajar Dari Hasil PISA 2018," Puspendik Kemendikbud, 2018. [Online]. Available: puspendik.kemendikbud.go.id. [Accessed 28 November 2021].

[2] M. Chatib, Gurunya Manusia, Bandung: Kaifa, 2019.

[3] D. William, Assesment for Learning: Why, What, and How?, London: Institute of Education, 2009.

[4] K. M.S., Andragogy in Action: Applying Modern Principles of Edult Learning, San Francisco: Jossey-Bass, 1984.

[5] A. Winarti, Pendidikan Orang Dewasa (Konsep dan Aplikasi), Bandung: Alfabeta, 2018.

[6] R. C. Bogdan and S. K. Biklen, Qualitative Research for Education: An Introduction to Theory and Methods, Boston: Alvin and Bacon, 1998.

[7] Sugiyono, Metodologi Penelitian Pendidikan, Bandung: Alfabeta, 2018.

[8] I. V. Mullis and Michael O. Martin, PIRLS 2016 Assesment Framework 2nd Edition, Boston: TIMSS \& PIRLS International Study Center, 2015.

[9] UNESCO, SDG 4 DATA DIGEST Data to Nature Learning, Canada: UNESCO Institute for Statistics, 2018.
[10] B. Allmon and Sara Freeman, Menjadi Guru Kreatif, Yogyakarta: Golden Book, 2010. 